International Journal of Social Sciences and Humanities
Available online at http://sciencescholar.us/journal/index.php/ijssh
Vol. 2 No. 3, December 2018, pages: 125 135
e-ISSN: 2550-7001, p-ISSN: 2550-701X
https://doi.org/10.29332/ijssh.v2n3.222

\title{
Strategy to Improve Knowledge, Attitude, and Skill Toward Clean and Healthy Life Behaviour
}

\author{
Moh. Arip ${ }^{a}$ Cembun $^{b}$, Desty Emilyani ${ }^{c}$ \\ Article history: Received 8 April 2018, Accepted: 30 August 2018, Published: 19 November 2018
}

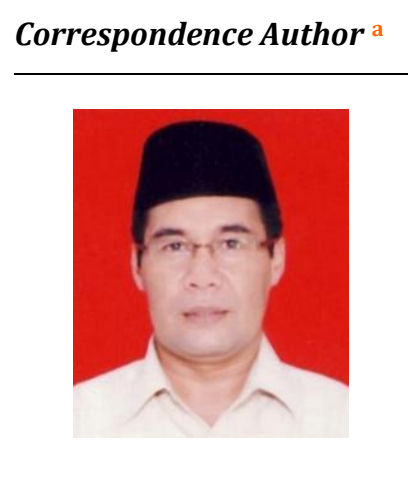

Keywords

Healthy life behaviour; KeRASA PHBS;

Elementary School;

Rudat dance;

Students;

\begin{abstract}
Various efforts must be conducted to provide a good understanding of PHBS to students. The approach applied to students has been using conventional counseling techniques, where the information is surely accepted by the target but few students who still remember the information and numerous students who lack attention because one-way counseling tends to be boring. The efforts done by health personnel have not been maximal. Therefore, the issue of delivering health information to students must be solved by other strategies, one of them is video media. It is designed to make the target acquires a proper understanding of PHBS easier. Video in this study derives from traditional dance of Lombok, called by Rudat which is performed by Elementary School students "KeRASA PHBS". It is an effort to utilize local cultural wisdom as a strategy to improve Knowledge, Attitude, and Skill for clean and healthy life behavior. The aim of this study was to find out the effectiveness of Rudat dance video of Elementary School students "KeRASA PHBS" as a Strategy to improve Knowledge, Attitude, and Skill to PHBS. This study used Quasy experimental with a pretest-posttest approach with Control-Group design. The findings within this study found that there was a significant difference between the intervention and control group. In terms of knowledge value $(p=0.005)$, attitude $(\mathrm{p}=0.000)$ and skill $(\mathrm{p}=0.000)$. In short, the intervention of Rudat dance video "KeRASA PHBS" is effective as a strategy to improve knowledge, attitude, and skill toward PHBS.
\end{abstract}

e-ISSN: 2550-7001, p-ISSN: 2550-701X ${ }^{\circ}$ Copyright 2018. The Author. SS Journals Published by Universidad Técnica de Manabí. This is an open-access article under the CC BY-SA 4.0 license (https://creativecommons.org/licenses/by-sa/4.0/) All rights reserved.

\footnotetext{
a Poltekkes Kemenkes Mataram, Indonesia

b Poltekkes Kemenkes Mataram, Indonesia

c Poltekkes Kemenkes Mataram, Indonesia
} 


\section{Contents}

Abstract

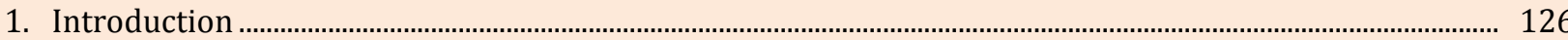

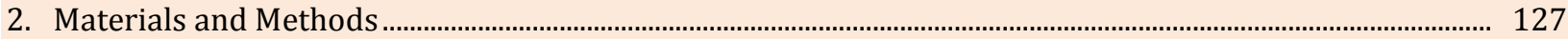

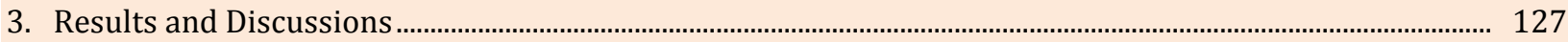

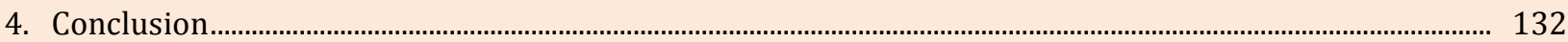

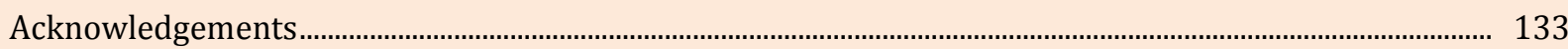

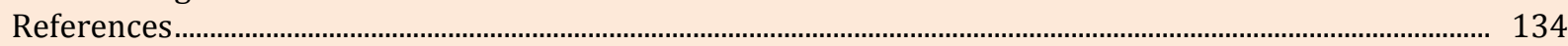

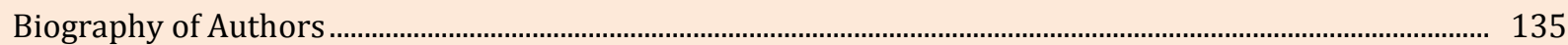

\section{Introduction}

Elementary school is the golden age to instill clean and healthy life behavior/perilaku hidup bersih dan sehat (PHBS) values and has the potential as an agent of change to promote PHBS in the schools, families, and communities thus the quality of human resources will be more qualified in the future. Data on the number of school children was estimated to reach 64.85 million in 2010 and estimated to reach 65.31 million in 2015. According to Notoatmodjo (2005) said that the population of children in Indonesia with the criteria of age 014 years is around $28 \%-34 \%$ of the total population of Indonesia. Therefore, a suitable place to provide socialization and early health practices for children is through schools.

The embodiment of school-age children as the next generation of the nation has implications for the need to pay special attention to school-age children both aspects of growth and development. According to Becker (1979) in Desmita (2009) stated that during school age, a lot of changes that occur in children include physical, cognitive, and psychosocial changes. Each change that occurs in school-age children can evoke risks such as accident risk and health risk. Therefore, this condition places school-age children as risky populations. The emergence of various diseases that often attack school-age children (6-12 years), generally related to PHBS (Indonesian Ministry of Health, 2011).

PHBS at an early age is good for educating and instilling awareness of the importance of hygiene as an effort to maintain personal health and the environment (Agarwal et al., 2017). The efforts toward PHBS that can be done for school-age children include hand washing with soap, eating fruit, meat and vegetables, snacks in a healthy school canteen, brushing teeth regularly, bathing and shampooing regularly, throwing garbage in its place, not smoking, weighing weight and measuring height every month, participating in sports activities at school, eradicating mosquito larvae regularly, defecating and urinating in school latrines and getting enough sleep. These indicators are a reflection of behavior that must be practiced both at school and at home. (Indonesian Ministry of Health, 2011).

Based on the interviews results with the Principal of Elementary School 1 Sembung in Narmada, there were still various conditions such as the lack of students' roles in participating in the activities of keeping school environment such as the activities of keeping cleaning on Friday. These activities include the cleanliness of the Classroom, Schoolyard, and Toilet. Students' understanding toward healthy life behavior is too lack, such as hand washing with soap, healthy foods, and beverages in the school canteen, defecating and urinating in school latrines, and personal hygiene and cleanliness of the school environment.

Conventional counseling has been applied frequently to improve students' understanding in PHBS but its result is not significant enough. Besides, One-way counseling tends to make students feel boring thus there are few students who still remember the messages of that counseling. Therefore, an effort that may be applied to improve students' understanding toward PHBS at Elementary School 1 Sembung in Narmada is a traditional dance of Sasak tribe that named by Rudat. Rudat dance video is claimed to be able to improve students' understanding toward PHBS because it is such a cultural potential. It is also considered, can attract the students' attention thus it is expected to improve students' understanding toward PHBS counseling (Culture \& Tourism Agency Mataram, 2011).

The potential of Rudat dance as a media of information for students is extremely great because its form like dance, music and one more person accompany with lyrics about PHBS, specifically relate to Handwashing with Soap (CTPS) hence the information which is delivered to students is strongly acquired. In connection with Rudat Dance, potentially as a media of information and counseling, the researchers are interested in 
conducting research with the title "The effectiveness of "KeRASA PHBS" video as a strategy to improve knowledge, attitude, and skill toward clean and healthy life behavior".

\section{Materials and Methods}

This study used queasy experimental with the "Pretest-Postest approach with Control-Group Design. Sampling technique was done by stratified random. The sample was several students of fourth and fifth grades at Elementary School 1 Sembung in Narmada, West Lombok with seventy-six students in which thirtyeight of control groups and thirty-eight of treatment groups. The independent variable is "KeRASA PHBS" Video while the dependent variable is knowledge, attitude, and skill. Data analysis for paired samples was Wilcoxon Signed-rank test and free samples using Mann-Whitney test with significance level $\mathrm{p}<0.05$.

\section{Results and Discussions}

\subsection{Characteristics of Respondents}

Table 1

Distribution of respondents by age, sex and class in the intervention and control groups at elementary school 1 Sembung in Narmada, West Lombok Regency on October 2017

\begin{tabular}{|c|c|c|c|c|c|}
\hline \multirow{3}{*}{ Characteristics } & \multicolumn{4}{|c|}{ Group } & \multirow{3}{*}{$\begin{array}{l}\text { Tota } \\
\mathrm{f}\end{array}$} \\
\hline & \multicolumn{2}{|c|}{ Intervention } & \multicolumn{2}{|c|}{ Control } & \\
\hline & $\mathrm{F}$ & $\%$ & $\mathrm{f}$ & $\%$ & \\
\hline \multicolumn{6}{|l|}{ Age } \\
\hline a. 9 years & 1 & 2.6 & 6 & 15.8 & 7 \\
\hline b. 10 years & 15 & 39.5 & 18 & 47.4 & 33 \\
\hline c. 11 years & 22 & 57.9 & 14 & 36.8 & 36 \\
\hline Total & 38 & 100.0 & 38 & 100.0 & 76 \\
\hline \multicolumn{6}{|l|}{ Sex } \\
\hline a. Male & 19 & 50.0 & 17 & 44.7 & 36 \\
\hline b. Female & 19 & 50.0 & 21 & 55.3 & 40 \\
\hline Total & 38 & 100.0 & 38 & 100.0 & 76 \\
\hline \multicolumn{6}{|l|}{ Class } \\
\hline a. Fourth & 18 & 47.4 & 19 & 50.0 & 37 \\
\hline b. Fifth & 20 & 52.6 & 19 & 50.0 & 39 \\
\hline Total & 38 & 100.0 & 38 & 100.0 & 76 \\
\hline
\end{tabular}

Based on Table 1 showed that the most proportion of age in the intervention group was eleven years or twenty-two respondents (57.9\%), then the age of ten years was fifteen respondents (39.5\%) and the lowest age was nine years or one respondent (2.6\%). Whereas, the most age proportion in the control group was ten years or eighteen respondents (47.4\%), then eleven years by fourteen respondents (36.8\%) and the lowest was nine years by six respondents $(15.8 \%)$.

The distribution of sex proportions in the intervention group and the control group was not too different. The proportions of gender in the intervention group either male or female was nineteen respondents (50.0\%) while in the female control group found twenty-one respondents (55.3\%) more than men by seventeen respondents $(44.7 \%)$.

The proportion of classes in the intervention group and the control group was not too different. The proportion of the class in the intervention group showed fifth grade by twenty respondents $(62.6 \%)$ more than a fourth grade of eighteen respondents (47.4\%) while in the control group each class (fourth and fifth grades) was nineteen respondents (50.0\%).

Arip, M., Cembun, -, \& Emilyani, D. (2018). Strategy to improve knowledge, attitude, and skill toward clean and healthy life behaviour. International Journal of Social Sciences and Humanities, 2(3), 125-135. https://doi.org/10.29332/ijssh.v2n3.222 


\subsection{Data Analysis}

Data analysis was conducted to determine the students' knowledge, Syaifuddin (1995), attitude and skill in fourth and fifth grades of Elementary School 1 Sembung in Narmada before and after the intervention.

Table 2

The difference of knowledge in pretest and posttest of intervention group at the elementary school 1 Sembung in Narmada, West Lombok Regency on October 2017

\begin{tabular}{lllll}
\hline Number & Knowledge & Mean & SD & p-value \\
\hline 1 & Pretest & 3.42 & 0.793 & \multirow{2}{*}{0,019}
\end{tabular}

Data in Table 2 indicated that the average value of students' knowledge before the intervention was 3.42 from thirty-eight students, while students' knowledge after the intervention was 3.87 of thirty-eight students. The results of statistical analysis obtained $\mathrm{p}<0.05$, which means that there is a significant difference in knowledge before and after counseling by using "KeRASA PHBS" video on the habit of hand washing with soap"

Table 3

The difference of knowledge in pretest and posttest of the control group at the elementary school 1 Sembung in Narmada, West Lombok Regency on October 2017

\begin{tabular}{lllll}
\hline Number & Knowledge & Mean & SD & p-value \\
\hline 1 & Pretest & 3.13 & 0.623 & 0,048 \\
2 & Posttest & 3.42 & 0.599 & \\
\hline
\end{tabular}

The data in Table 3 showed the average value of students 'knowledge before the intervention was 3.13 from thirty-eight students, while the students' knowledge after the intervention was 3.42 from thirty-eight students. The results of statistical analysis gained $\mathrm{p}<0.05$, which means there is a significant difference in knowledge before and after counseling conventional methods.

Table 4

The difference of attitude in pretest and posttest of intervention group at the elementary school 1 Sembung in Narmada, West Lombok Regency on October 2017

\begin{tabular}{lllll}
\hline Number & Attitudes & Mean & SD & p-value \\
\hline 1 & Pretest & 11.95 & 1.627 & \multirow{2}{*}{0,012} \\
2 & Posttest & 12.47 & 1.289 & \\
\hline
\end{tabular}

Based on the data in Table 4, the average score of students' attitude before the intervention was 11.95 from thirty-eight students, whereas students' attitudes after the intervention was 12.47 from thirty-eight students. The results of statistical analysis obtained $\mathrm{p}<0.05$, which means that there is a significant difference in attitude before and after counseling by using "KeRASA PHBS" video on the habit of hand washing with soap"

Table 5

The difference of attitude in pretest and posttest of the control group at the elementary school 1 Sembung in Narmada, West Lombok Regency on October 2017

\begin{tabular}{lllll}
\hline Number & Attitudes & Mean & SD & p-value \\
\hline 1 & Pretest & 10.39 & 1.685 & 0,059 \\
2 & Posttest & 10.87 & 1.436 & \\
\hline
\end{tabular}


The data in Table 5, the average score of students' attitude before the intervention was 10.39 of thirty-eight students, while students' attitude after the intervention was 10.87 of thirty-eight students. The results of statistical analysis obtained $\mathrm{p}>0.05$, which means there is no difference in attitude before and after counseling by conventional methods.

Table 6

The difference of skill in pretest and posttest of intervention group at the elementary school 1 Sembung in Narmada, West Lombok Regency on October 2017

\begin{tabular}{lllll}
\hline Number & Skills & Mean & SD & p-value \\
\hline 1 & Pretest & 5.68 & 1.165 & 0,006 \\
2 & Post test & 6.26 & 0.795 & 006 \\
\hline
\end{tabular}

The data in Table above indicated the average score of students'skill before the intervention was 5.68 from thirty-eight students, whereas the average score of students' skill after the intervention was 6.26 from thirtyeight students. The results of the statistical analysis found $p<0.05$, which means that there is a significant difference in skills before and after counseling by using "KeRASA PHBS" video on the habit of hand washing with soap"

Table 7

The difference of skill in pretest and posttest of the control group at the elementary school 1 Sembung in Narmada, West Lombok Regency on October 2017

\begin{tabular}{lllll}
\hline Number & Skills & Mean & SD & p-value \\
\hline 1 & Pretest & 3.76 & 0.883 & \multirow{2}{*}{0,052} \\
2 & Posttest & 4.08 & 0.673 & \\
\hline
\end{tabular}

Based on the data in Table 7, the average score of students'skill before the intervention was 3.76 from thirtyeight students, while the average value of students' skill after the intervention was 4.08 of thirty-eight students. The results of statistical analysis obtained $\mathrm{p}>0.05$, which means there is no difference in skills before and after counseling by conventional methods.

Table 8

Comparison of posttest results of knowledge between intervention and control groups at an elementary school 1 Sembung in Narmada, West Lombok Regency on October 2017

\begin{tabular}{llll}
\hline Number & Knowledge & Mean & p-value \\
\hline 1 & Intervention & 3.87 & \multirow{2}{*}{0,005} \\
2 & Control & 3.42 & \\
\hline
\end{tabular}

The data above showed, the students' knowledge after counseling by using method of "KeRASA PHBS" video on the habit of hand washing with soap" in the intervention group obtained an average value of 3.87.whereas, the control group obtained an average value of 3.42. Based on the results of the Mann Whitney test the $\mathrm{p}<$ 0.05. it means that there is a significant difference in the value of the knowledge of the intervention with the control group.

Arip, M., Cembun, -, \& Emilyani, D. (2018). Strategy to improve knowledge, attitude, and skill toward clean and healthy life behaviour. International Journal of Social Sciences and Humanities, 2(3), 125-135. https://doi.org/10.29332/ijssh.v2n3.222 
Table 9

Comparison of posttest results of attitude between intervention and control groups at an elementary school 1 Sembung in Narmada, West Lombok Regency on October 2017

\begin{tabular}{llll}
\hline Number & Attitudes & Mean & p-value \\
\hline 1 & Intervention & 12.47 & 0 \\
2 & Control & 10.87 & \\
\hline
\end{tabular}

Based on the table above, students' attitude after counseling of Rudat dance (KeRASA PHBS) video methods in the intervention group gained an average value of 12.47 while the control group obtained 10.87. Based on the results of the Mann Whitney test found that $\mathrm{p}<0.05$. it indicates that there is a significant difference in the value of the attitude of the intervention group with the control group.

Table 10

Comparison of posttest results of skill between intervention and control groups at an elementary school 1 Sembung in Narmada, West Lombok Regency on October 2017

\begin{tabular}{llll}
\hline Number & Skills & Mean & p-value \\
\hline 1 & Intervention & 6.26 & 0,000 \\
2 & Control & 4.08 & \\
\hline
\end{tabular}

The data in Table 10 showed Students' skill after counseling of Rudat dance (KeRASA PHBS) video methods on the habit of handwashing with soap in the intervention group obtained an average value of 6.26. Whereas the control group obtained an average value of 4.08. Based on the results of the Mann Whitney test found that $p<$ 0.05. This shows that there is a significant difference in the value of Skills of the intervention group with the control group.

\subsection{Discussion}

According to WHO data stated that $67 \%$ of children die as the effect of environmental-based diseases such as diarrhea, Upper Respiratory Track Infections (URI), Dengue Hemorrhagic Fever (DHF), Malaria, Tuberculosis, and other environmental diseases. In addition, a number of diarrhea cases on children are gradually increasing every year. It is caused by children habits who are not clean. E.coli bacteria causes diarrhea and it is usually found in unclean environments. Based on the observation results of sub-directorate of diarrhea, found that 2.253 cases $(38.11 \%)$ in 2008 .

The number of educational institutions in Indonesia, especially Elementary Schools, is 338.729, which was reported on July 27, 2011. The emergence of various diseases that often attack school-age children (6-10 years), is generally related to clean and healthy life behavior (PHBS). In addition, the issue of foods safety sold around schools that have not applied the principles of hygiene. If PHBS counseling is not done well, it will cause undesirable effects, namely the emergence of various diseases.

Based on the research findings conducted in August to September 2017 at Elementary School 1 Sembung, 76 students of fourth and fifth grades became respondents. Moreover, the sample was divided into two groups, 38 respondents were Intervention group and 38 group respondents belong to the control group.

\section{a) Knowledge}

After conducted pretest of knowledge in Rudat dance (KeRASA PHBS) video methods group showed an average value of 3.42 and posttest results was 3.87. The analysis results presented that there was a difference in knowledge before and after counseling by using the video. In contrast, The pretest of knowledge in conventional counseling group showed an average value of 3.13 and the posttest results was 3.42 . The analysis results exhibited that there was a difference in knowledge before and after counseling of the conventional method. 
Knowledge is the result of "knowing" and this occurs after the respondent has sensed a certain object. A human sense occurs through sight, smell, taste, and touch. Most of the knowledge is obtained through the eyes and ears where knowledge can be acquired through self-experience as well as from others. Knowledge is a domain that is very vital for creating one's actions.

According to Zahara Idris (1992) stated that knowledge is not only influenced by formal education but also informal by means of self-experiences or others as well as counseling and other information, for instance, the existence of posters and news from the mass and electronic media about clean and healthy lifestyles thus people can understand them easier and improve their knowledge. In addition, Robert \& Bacon (1971) who argued that "behavior change is influenced by communication". Counseling activities are one form of communication that carried out to convey health messages such as hand washing with soap (CTPS) by using Rudat dance (KeRASA PHBS) video. This method is expected to be able to reach the right target specifically students of Elementry School 1 Sembung in Narmada, West Lombok Regency.

Moreover, from discussion and interview conducted to several students who have high knowledge, CTPS counseling is not only the source of knowledge but students also acquire health knowledge from electronic media and parents. One of the students has parents who work as a teacher thus it can be concluded that one's knowledge is not only obtained from the information conveyed during formal activities but also in their environment, their daily activities hence they can improve their knowledge.

In connection with these phenomena, the results of comparative analysis proved that counseling on CTPS using Rudat dance (KeRASA PHBS) video could improve respondents' knowledge compared to the conventional method.

\section{b) Attitudes}

Based on the research findings pretest toward attitude in the intervention group (KeRASA PHBS) showed an average value of 11.95 and posttest attitude exhibited 12.47. The analysis results exhibited a difference in attitude before and after counseling of (KeRASA PHBS) video method. Whereas, a pretest of attitude in conventional method group revealed an average value of 10.39 and posttest attitude was 10.87 . The analysis results indicated that there was no difference in attitudes before and after the intervention with the conventional method (Khayati, 2008).

In line with the theory, behavior changes started from the stage of knowledge which will later influence attitude and continue to actions as a form of knowledge application. According to Notoatmodjo (2007) said that attitude is an assessment, it can be someone's opinion towards stimulation or object which refers to a health problem. After someone knows the stimulation or object, the process will then assessor behave towards the stimulation or the object. Therefore, indicators for healthy attitudes are also in line with health experiences such as 1) attitude toward sickness and disease. It refers to a person's opinion on symptoms, causes, methods of transmission and prevention method diseases, 2) Attitude towards how to maintain a healthy life. It refers to someone's opinion about ways to maintain and how to behave a healthy life. In other words, opinions toward food, beverage, exercise and adequate rest. 3) Attitude towards environmental health, which means one's opinions about the environment and its effects on health. Environment refers to the opinion of clean water, waste disposal, and pollution.

The tendency of school children to adopt clean and healthy behavior is an existence of school children interaction. Attitude possess a role as experiences management hence students will become homogeneous in acting to implement a clean and healthy lifestyle, especially for their own health

If attitude is connected to facilities, although the children already have a positive attitude towards the implementation of PHBS if the facilities are inadequate or not available then it will also affect the implementation of PHBS. It can be illustrated such as the attitude of handwashing with running water and using soap if water is available but soap and the tap facilities are not available, then the implementation of PHBS will be not optimal, as well as other PHBS systems such as healthy canteens, adequate sports facilities, and other facilities.

In line with research findings, that the average students' attitude after counseling of Rudat dance video method (12.47) was higher than conventional counseling method (10.87). It means that there is a significant difference in attitudes towards the implementation of both methods $(p=0,000)$. According to Green \& Kreuter (1991) stated that one's interest to an object or response can encourage someone to give a positive assessment to this response because a person's attitude connotes a person's response to an object. In the

Arip, M., Cembun, -, \& Emilyani, D. (2018). Strategy to improve knowledge, attitude, and skill toward clean and healthy life behaviour. International Journal of Social Sciences and Humanities, 2(3), 125-135. https://doi.org/10.29332/ijssh.v2n3.222 
interview section during counseling, Several students said that they were very interested in the topic of counseling on Handwashing with Soap using the Rudat dance video method which performed by elementary school students. Students also said, "It was easier to understand and follow the method because of the movement of dance in accordance with the seven steps of hand washing with soap "CTPS movement".

\section{c) Skill}

Based on Research findings, the pretest of skill in the intervention group by using Rudat dance video revealed an average value of 5.68 and posttest result of skill 6.26. The analysis results stated that there was a difference in skill before and after counseling with the Rudat dance video method $(p=0.006)$. Whereas, The pretest of skill in the conventional counseling group showed an average value of 3.76 and the posttest results exhibited (4.08). The analysis results found that there is no difference in skill before and after the intervention with the conventional counseling method $(p=0.052)$.

Based on the research findings, in terms of students' knowledge and attitudes aspect at Elementary School 1 Sembung indicates that there is a significant difference in students' skill $(p=0.000)$ between the intervention of Rudat dance video method and conventional counseling method. It is in line with the theory of behavior change, starting from the stage of knowledge which will later influence attitude and continue to act as a form of knowledge application.

According to Notoatmodjo (2007), an attitude has not automatically materialized in an action. Creating an attitude into a real act needs supporting factors such as facilities. Practice or skill has several levels, namely; 1) guided response. It refers to doing something in the right order and according to the example is an indicator of first level skill. For example, a mother can cook vegetables properly, starting from how to wash and cut them, cooking duration, closing the pan and so on. 2) Mechanism. It means that if someone has been able to do something properly, it is already a habit and called by the second level of skill. For example, a mother who has immunized her baby at a certain age, without waiting for orders or invitations from others. 3) Adoption is a skill that has already developed well. It means that the skill has been modified without decreasing the correctness of the action. For example, a mother can choose and cook high nutritious food based on cheap and simple ingredients.

The existence of a difference in the value of respondents' knowledge and attitudes about CTPS, is also shown in the difference in the value of skill towards the group of Rudat dance video method and conventional counseling method group. This phenomenon is in line with the Hariweni (2002) research, found that there was a significant difference in the level of mothers' knowledge, attitudes and behavior about stimulation of children are between career women and housewive. Moreover, As stated in the research of Wachidanijah (2002) stated: "there is a correlation between knowledge and attitudes towards the respondents' practice". If respondents' knowledge and attitude are better, then respondents' practice is better too in making effort to prevent worm infection. This study is proven that the higher value of respondents' knowledge and attitude, then the higher value of respondents' skill in conducting CTPS.

According to Green (1980) in Notoatmodjo (2005) stated that the method of conventional counseling is less effective to change attitude and skill. A learning process will develop when using various learning methods. Therefore, a learning or counseling process on Handwashing with Soap (CTPS) carried out using the Rudat dance video method can be used as a method that is quite effective to improve students' knowledge, attitude, and skill. It is in line with the principle of learning by doing.

In connection with the phenomena above, this study proves that the value of respondents' skill after counseling with the Rudat dance video method is different between two groups. A development of the average value of skill in the Rudat dance video group is higher than the conventional group method.

\section{Conclusion}

The intervention of Rudat dance (KeRASA PHBS) video is effective as a strategy to develop knowledge, attitude, and skill towards Clean and Healthy Life Behavior. 


\section{Suggestion}

a) Students' knowledge, attitude, and skill, which is already good in handwashing with soap (CTPS) need maintaining, developed, and spreading to other students and families who have never received this counseling.

b) Training and counseling need to be done with the tutorial of this video by teachers at Elementary School 1 Sembung, especially to students whose results of knowledge, attitude and skill assessment are less during this study.

c) The recommendation of policy is needed in program planning for the sustainability of the research findings hence this program can be implemented at all Elementary Schools in the Province of West Nusa Tenggara and Indonesia.

d) Cross-program and cross-sectoral collaboration are needed to accelerate the socialization and application of this video thus it reaches all school communities and other general public.

\section{Acknowledgments}

Thank Almighty God for all His blessing, so that the author can finish this research. Deep and sincere gratitude for those who have helped and guided the author to complete this research included the Head of Research and Development Unit Poltekkes Kemenkes Mataram who always give support and motivate the author to conduct this research, the Head of Nursing Departement Poltekkes Kemenkes Mataram who has patiently give her guidance, support and encouragement to complete this research, the Director of Poltekkes Kemenkes Mataram who has given the opportunity to the author to conduct this research. Also to all staff and lecturers in Nursing Departement Poltekkes Kemenkes Mataram who have to give motivation and encouragement to complete this research. Deepest gratitude to all family who has patiently support, encourage and accompany the author, and keep the author motivated during the process of this research. Also to all people that provide assistance and support during the process of completing this research.

Arip, M., Cembun, -, \& Emilyani, D. (2018). Strategy to improve knowledge, attitude, and skill toward clean and healthy life behaviour. International Journal of Social Sciences and Humanities, 2(3), 125-135. 


\section{References}

Agarwal, R., Jain, P., Ghosh, M. S., \& Parihar, K. S. (2017). Importance of Primary Health Care in the Society. International Journal of Health Sciences (IJHS), 1(1), 6-11.

Becker, C. A. (1979). Semantic context and word frequency effects in visual word recognition. Journal of Experimental Psychology: Human Perception and Performance, 5(2), 252.

Depertemen Kesehatan RI. (2009). Pembinaan Perilaku Hidup Bersih dan Sehat di Berbagai Tatanan. Pusat Promosi Kesehatan.

Desmita, D. (2009). Psikologi Perkembangan Peserta Didik. Remaja Rosdakarya.

Dinas Kebudayaan \& Pariwisata Kota Mataram. (2011). Seni Panduan Wisata 2011. Kota Mataram.

Green, L. W., \& Kreuter, M. W. (1991). Health promotion planning: an educational and environmental approach. In Health promotion planning: an educational and environmental approach. Mayfield.

Green, L. W., Kreuter, M. W., Deeds, S. G., Partridge, K. B., \& Bartlett, E. (1980). Health education planning: a diagnostic approach.

Hariweni, T. (2003). Pengetahuan, Sikap dan Perilaku Ibu Bekerja dan Tidak Bekerja Tentang Stimulasi Pada Pengasuhan Anak (Master's thesis).

Idris, Z., \& Jamal, L. (1992). Pengantar pendidikan. Gramedia Widiasarana Indonesia (Grasindo).

Kementerian Kesehatan RI. (2011). PHBS di Sekolah. Jakarta: Kementrian Kesehatan RI.

Khayati, N. (2008). berjudul "Perilaku Hidup Sehat Siswa Kelas IV, V, dan VI SD Negeri Banyuurip Dlingo Bantul.

Notoatmodjo, S. (2007). Promosi kesehatan dan ilmu perilaku. Jakarta: Rineka Cipta, 20.

Notoatmodjo, S., \& Kesehatan, P. (2005). Teori dan Aplikasi. Jakarta: Penerbit Rineka Cipta.

Proverawati, A., \& Rahmawati, E. (2012). Perilaku hidup bersih dan sehat (PHBS). Yogyakarta: Nuha Medika.

Roberts, J. A., \& Bacon, D. R. (1997). Exploring the subtle relationships between environmental concern and ecologically conscious consumer behavior. Journal of business research, 40(1), 79-89.

Syaifuddin, A. (1995). Sikap Manusia Teori dan Pengukurannya.

Wachidanijah, S. (2002). Sikap dan Perilaku Anak Serta Lingkungan Rumah dan Sekolah dengan Kejadian Infeksi Kecacingan Anak Sekolah Dasar (Studi di Kecamatan Prembun Kabupaten Kebumen). Berita Kedokteran Masyarakat, 18(4), 177-183. 


\section{Biography of Authors}

\begin{tabular}{||l|l||}
\hline \hline & $\begin{array}{l}\text { Moh. Arip was born in East Lombok, June 7th, 1967. He graduated his bachelor } \\
\text { degree of nursing in Universitas Indonesia in 1998. He finished his master degree } \\
\text { in society health science, Universitas Airlangga. He interested in basic concepts of } \\
\text { nursing, child nursing, and introduction to nursing research. He works at } \\
\text { Poltekkes Kemenkes Mataram, Jln. Prabu Rangkasari Dasan Cermen Sandubaya, } \\
\text { Mataram, Ph. +62370-631160, Fax. +62370-721383 } \\
\text { Email: moharip_mkes@yahoo.co.id }\end{array}$ \\
\hline \hline & $\begin{array}{l}\text { Cembun was born in Telaga Ngembang, December 31st, 1965. He graduated his } \\
\text { diploma IV of educational nursing, Universitas Airlangga in 1999. He finished his } \\
\text { master degree in society health science, Universitas Gadjah Mada. Family Nursing, } \\
\text { Community Nursing (PHC), Behavior and Health Promotion. He works at } \\
\text { Poltekkes Kemenkes Mataram, Jln. Prabu Rangkasari Dasan Cermen Sandubaya, } \\
\text { Mataram, Ph. +62370-631160, Fax. +62370-721383 } \\
\text { Email: cembunmph@gmail.com }\end{array}$ \\
\hline
\end{tabular}

Arip, M., Cembun, -, \& Emilyani, D. (2018). Strategy to improve knowledge, attitude, and skill toward clean and healthy life behaviour. International Journal of Social Sciences and Humanities, 2(3), 125-135. https://doi.org/10.29332/ijssh.v2n3.222 